\title{
The Strategic Application of Electrolyte Balance to Minimize Heat Stress in Broilers
}

http://dx.doi.org/10.1590/1516-635x1702237-246

\section{-Author(s)}

Gamba JPI

Rodrigues MM"

Garcia Neto M"

Perri SHVIV

Faria Júnior MJ de $A^{\prime \prime \prime}$

Pinto MF"II
M. Sc. In Animal Science
DVM
III Associate Professor at FMVA-UNESP
Iv Ph.D., Associate Professor at FMVA- UNESP

\section{ABSTRACT}

Several physiological and metabolic changes are triggered in broilers submitted to high environmental temperatures, resulting in performance losses. Feed formulation manipulation of the dietary electrolyte balance may be applied to reduce the negative impact of heat stress on broiler performance. This experiment was carried out to evaluate the effect of the manipulations of dietary electrolytes by combining changes in the electrolyte $\left(\mathrm{Na}^{+}+\mathrm{K}^{+}-\mathrm{Cl}^{-}\right)$balance $(\mathrm{EB})$ and in the $\left[\left(\mathrm{K}^{+}+\mathrm{Cl}\right) / \mathrm{Na}^{+}\right]$ratio (ER) in broiler feeds. In total, 1575 male broilers between 21 and 46 days old were allotted to 15 treatments in a $5 \times 3$ factorial arrangement, consisting of five diets with different EB/ER combinations (150/3, 250/2, 250/3, 250/4, and 350/3). Birds were submitted to heat stress at 25 or 35 days old. Live performance, mortality rate, and carcass traits were evaluated. The strategic formulation of diets with different EB and ER improves live performance and minimize the effect of heat stress on broilers. Under thermoneutral conditions, an EB of $250 \mathrm{mEg} / \mathrm{kg}$ and an ER of 3 are recommended, whereas under heat stress, and EB of 350 $\mathrm{mEq} / \mathrm{kg}$ and an ER of 3 should be applied.

\section{INTRODUCTION}

Broiler susceptibility to heat stress increase as air relative humidity and environmental temperature values exceed the thermal comfort zone $\left(16-23^{\circ} \mathrm{C}\right.$ and $\left.50-70 \%\right)$ (Tinoco, 1998), making it difficult for birds to dissipate heat. Consequently, their body temperature increase, negatively affecting their performance.

The addition of salts to the drinking water or to the feed is frequently employed in broiler production to reduce losses caused by heat stress. The main salts used are potassium chloride $(\mathrm{KCl})$ and sodium bicarbonate $\left(\mathrm{NaHCO}_{3}\right)$ (Cahaner \& Leenstra, 1992; Yalçin et al., 2001).

The minerals $\mathrm{K}^{+}, \mathrm{Na}^{+}$and $\mathrm{Cl}^{\text {- }}$, in particular, play essential roles in metabolism due to their participation in the osmotic balance, in the acid-base balance, and in the integrity of mechanisms that regulate the transport of substances across the cell membranes. Imbalances among those minerals have a direct effect on acid-base balance, affecting many metabolic functions, and therefore, broiler performance (Judice et al., 2002).

The environment and the diet influence the acid-base balance. Maintaining this balance is essential to improve the performance of broilers reared under high temperatures and to overcome the damaging effects of respiratory alkalosis produced by heat stress (Teeter \& Belay, 1996).

Previously, only the acid-base balance $\left(\mathrm{K}^{+}, \mathrm{Na}^{+}\right.$and $\left.\mathrm{Cl}^{-}\right)$minimum requirements for each rearing phase was previously considered in diet formulation (NRC, 1994), However, according to Mongin (1981), 
the proportions (difference and ratio) among those minerals should be adjusted to provide better electrolyte balance with the aim of maintaining physiological acid-base homeostasis, and thereby, optimal growth performance (Gezen et al., 2005).

Mongin (1981) also emphasizes that diets should contain not only an adequate electrolyte balance, given by the difference $\left(\mathrm{Na}^{+}+\mathrm{K}^{+}-\mathrm{Cl}\right)$, but also adequate electrolyte ratio $\left[\left(\mathrm{K}^{+}+\mathrm{Cl}^{-}\right) / \mathrm{Na}^{+}\right]$. Therefore, the adequate ratio between $\mathrm{K}^{+}, \mathrm{Na}^{+}$and $\mathrm{Cl}^{-}$needs to be considered in addition to the calculation of the difference between the total concentration of anions and cations (Talbolt, 1978).

The present experiment was carried out to experiment was carried out to evaluate the effect of the manipulations of dietary electrolyte balance based on combinations of different electrolyte balances and electrolyte ratios on the performance, mortality, and carcass traits of broilers submitted to heat stress.

\section{MATERIAL AND METHODS}

The experiment was carried out at the Animal Science Experimental Sector of the School of Veterinary Medicine of Universidade Estadual Paulista (UNESP), Araçatuba campus, state of São Paulo, Brazil. In total, 1575 male broilers belonging to the same commercial genetic strain, were evaluated between 21 and 46 days of age.

Birds were housed in a masonry broiler house (7.85 $x 45.70 \mathrm{~m}$ ) built in the East-West direction, equipped with an adiabatic evaporative cooling system and negative-pressure ventilation, and covered with special tiles made of insulating material (expanded polystyrene) placed under reflecting metal plates. Birds were distributed in floor pens $(1.4 \times 3.0 \mathrm{~m})$ with wood-shavings litter, and equipped with automatic feeders and drinkers. Each pen was considered as an experimental unit.

At 21 days of age, chicks were weighed and randomly distributed to the pens, which housed 35 birds each. A lighting program of 18 hours of light (12 hours of natural light + six hours of artificial light) was applied. Birds were fed with five diets consistingwith ofdifferent electrolyte balances, inaccording to accordance with the subsequent treatments, and keptmaintained under in thermoneutral conditions.

Treatments consisted of diets containing five different electrolyte balances, derived from the $\mathrm{EB} /$ ER combinations of 150/3, 250/2, 250/3, 250/4, and $350 / 4$, shown in Table 1, and thermal environments (thermoneutral conditions or acute heat stress). Acute heat stress was or not applied when birds were 25 or 35 days old, and fed the same diet of other treatments.

Table 1 - Electrolyte balance (EB) and electrolyte ratio (ER) combinations applied in the experimental diets.

\begin{tabular}{llll}
\hline$E^{1}$ & $\mathrm{~EB}^{2}$ & & \\
\cline { 2 - 4 } & 150 & 250 & 350 \\
\hline $2: 1$ & & $X$ & \\
\hline $3: 1$ & $\times$ & $X$ & \\
\hline $4: 1$ & & $X$ & \\
\hline $1-$ Electrolyte ratio & & & \\
$2-$ Electrolyte balance & & &
\end{tabular}

Evaluations were carried out when birds were 33 (day 33) and 46 (day 46) days old. On day 33, data were analyzed according to completely randomized experimental design in a $5 \times 2$ factorial arrangement (five $E B / E R$ combinations $x$ two environmental temperatures), totaling 10 treatments (Table 2), with six replicates of birds maintained under thermoneutral conditions and three replicates of birds submitted to heat stress on day 25. Each replicate contained 35 birds. On day 46, responses were analyzed according to completely randomized experimental design in a $5 \times 3$ factorial arrangement was applied, totaling 15 treatments (Table 2), with three replicates of 35 birds each. The model of the analysis of variance is presented in Table 3.

Table 2 - Treatments according to electrolyte balance and ratio combinations and thermal environment.

\begin{tabular}{|c|c|c|c|}
\hline Treatment & $\operatorname{Diet}\left(E B^{*} / E R^{* *}\right)$ & Evaluation day 33 & Evaluation day 46 \\
\hline 1 & $150 / 3$ & No heat stress & No heat stress \\
\hline 2 & $250 / 2$ & No heat stress & No heat stress \\
\hline 3 & $250 / 3$ & No heat stress & No heat stress \\
\hline 4 & $250 / 4$ & No heat stress & No heat stress \\
\hline 5 & $350 / 3$ & No heat stress & No heat stress \\
\hline 6 & $150 / 3$ & Heat stress d 25 & Heat stress d 25 \\
\hline 7 & $250 / 2$ & Heat stress d 25 & Heat stress d 25 \\
\hline 8 & $250 / 3$ & Heat stress d 25 & Heat stress d 25 \\
\hline 9 & $250 / 4$ & Heat stress d 25 & Heat stress d 25 \\
\hline 10 & $350 / 3$ & Heat stress d 25 & Heat stress d 25 \\
\hline 11 & $150 / 3$ & --- & Heat stress d 35 \\
\hline 12 & $250 / 2$ & --- & Heat stress d 35 \\
\hline 13 & $250 / 3$ & --- & Heat stress d 35 \\
\hline 14 & $250 / 4$ & --- & Heat stress d 35 \\
\hline 15 & $350 / 3$ & --- & Heat stress d 35 \\
\hline
\end{tabular}

* Electrolyte ratio; ** Electrolyte balance 
The experimental diets were based on corn, soybean meal, corn gluten, soybean oil, vitamin and mineral supplement, calcitic limestone, and dicalcium phosphate, and formulated according to the recommendations of Rostagno et al.(2005) (Table 4). Salt $\left(\mathrm{NaCl}, \mathrm{NaHCO}_{3}, \mathrm{~K}_{2} \mathrm{SO}_{4}\right)$ levels were included to supply minimum $\mathrm{K}^{+}, \mathrm{Na}^{+}$and $\mathrm{Cl}^{-}$requirements and adjusted according to the electrolyte combinations of each experimental diet. Feed was manufactured in the experimental feed mill of the Animal Science Experimental Sector, UNESP.
Table 3 - Model of the analysis of variance of the experiment.

\begin{tabular}{lcc}
\hline Sources of variation & \multicolumn{2}{c}{ Degrees of freedom } \\
\hline Total & Day 33 & Day 46 \\
\hline Diet $\left(E B^{*} / \mathrm{ER}^{* *}\right)$ & 44 & 44 \\
\hline Heat stress $(H S)$ & 4 & 4 \\
\hline Diet $x$ HS & 1 & 2 \\
\hline Error & 4 & 8 \\
\hline
\end{tabular}

* Electrolyte ratio; ** Electrolyte balance

Table 4 - Ingredients and calculated composition of the diets fed to the broilers during the grower and finisher phases.

\begin{tabular}{|c|c|c|c|c|c|c|c|c|c|c|c|}
\hline \multicolumn{12}{|c|}{ Electrolyte combination (EB/ER)* } \\
\hline & & \multicolumn{5}{|c|}{ Grower (21-33 days) } & \multicolumn{5}{|c|}{ Finisher diet (33-46 days) } \\
\hline Ingredients & & $150 / 3$ & $250 / 2$ & $250 / 3$ & $250 / 4$ & $350 / 3$ & $150 / 3$ & $250 / 2$ & $250 / 3$ & $250 / 4$ & $350 / 3$ \\
\hline Corn & $\%$ & 61.31 & 56.64 & 54.16 & 55.73 & 52.32 & 63.65 & 60.78 & 58.14 & 57.62 & 56.25 \\
\hline Corn gluten meal $60 \%$ & $\%$ & 4.22 & 0.00 & 0.00 & 0.00 & 0.00 & 2.21 & 0.00 & 0.00 & 0.00 & 0.00 \\
\hline Soybean oil & $\%$ & 3.35 & 5.26 & 5.60 & 5.45 & 6.23 & 4.71 & 5.82 & 6.27 & 6.45 & 6.91 \\
\hline Soybean meal $45 \%$ & $\%$ & 26.86 & 33.56 & 36.16 & 34.23 & 36.48 & 25.91 & 29.64 & 32.04 & 32.13 & 32.36 \\
\hline Dicalcium phosphate & $\%$ & 1.70 & 1.69 & 1.67 & 1.69 & 1.68 & 1.44 & 1.44 & 1.43 & 1.43 & 1.43 \\
\hline Salt & $\%$ & 0.51 & 0.42 & 0.23 & 0.48 & 0.21 & 0.49 & 0.15 & 0.17 & 0.39 & 0.17 \\
\hline L-lysine & $\%$ & 0.33 & 0.17 & 0.08 & 0.15 & 0.08 & 0.27 & 0.18 & 0.10 & 0.10 & 0.10 \\
\hline DL-methionine & $\%$ & 0.20 & 0.24 & 0.22 & 0.23 & 0.22 & 0.19 & 0.21 & 0.19 & 0.19 & 0.19 \\
\hline L-threonine & $\%$ & 0.05 & 0.03 & 0.00 & 0.03 & 0.00 & 0.04 & 0.03 & 0.00 & 0.00 & 0.00 \\
\hline Calcitic limestone & $\%$ & 0.88 & 0.85 & 0.84 & 0.85 & 0.84 & 0.79 & 0.78 & 0.77 & 0.77 & 0.77 \\
\hline Sodium bicarbonate & $\%$ & 0.00 & 0.54 & 0.36 & 0.00 & 0.59 & 0.00 & 0.69 & 0.41 & 0.07 & 0.62 \\
\hline Potassium sulfate & $\%$ & 0.00 & 0.00 & 0.07 & 0.58 & 0.76 & 0.00 & 0.00 & 0.18 & 0.56 & 0.90 \\
\hline Supplement - grower** & $\%$ & 0.60 & 0.60 & 0.60 & 0.60 & 0.60 & 0.00 & 0.00 & 0.00 & 0.00 & 0.00 \\
\hline Supplement - finisher*** & $\%$ & 0.00 & 0.00 & 0.00 & 0.00 & 0.00 & 0.30 & 0.30 & 0.30 & 0.30 & 0.30 \\
\hline Metab. energy & $\mathrm{kcal} / \mathrm{kg}$ & 3150 & 3150 & 3150 & 3150 & 3150 & 3250 & 3250 & 3250 & 3250 & 3250 \\
\hline Crude protein & $\%$ & 20.25 & 20.21 & 21.07 & 20.41 & 21.05 & 18.72 & 18.76 & 19.53 & 19.52 & 19.51 \\
\hline Calcium & $\%$ & 0.84 & 0.84 & 0.84 & 0.84 & 0.84 & 0.74 & 0.74 & 0.74 & 0.74 & 0.74 \\
\hline Available P & $\%$ & 0.42 & 0.42 & 0.42 & 0.42 & 0.42 & 0.37 & 0.37 & 0.37 & 0.37 & 0.37 \\
\hline Potassium & $\%$ & 0.67 & 0.77 & 0.84 & 1.02 & 1.13 & 0.66 & 0.71 & 0.82 & 0.98 & 1.12 \\
\hline Sodium & $\%$ & 0.22 & 0.33 & 0.21 & 0.21 & 0.26 & 0.21 & 0.26 & 0.20 & 0.19 & 0.25 \\
\hline Chlorine & $\%$ & 0.41 & 0.33 & 0.20 & 0.36 & 0.18 & 0.39 & 0.17 & 0.17 & 0.30 & 0.17 \\
\hline Linoleic acid & $\%$ & 3.16 & 4.10 & 4.25 & 4.19 & 4.56 & 3.91 & 4.45 & 4.66 & 4.75 & 4.97 \\
\hline Dig. Lysine & $\%$ & 1.10 & 1.10 & 1.10 & 1.10 & 1.10 & 1.02 & 1.02 & 1.02 & 1.02 & 1.02 \\
\hline Dig. methionine & $\%$ & 0.50 & 0.52 & 0.51 & 0.51 & 0.51 & 0.46 & 0.47 & 0.46 & 0.46 & 0.46 \\
\hline Dig.Methionine + cystine & $\%$ & 0.79 & 0.79 & 0.79 & 0.79 & 0.79 & 0.73 & 0.73 & 0.73 & 0.73 & 0.73 \\
\hline $\mathrm{EB}=\mathrm{Na}+\mathrm{K}-\mathrm{Cl}$ & $\mathrm{kcal} / \mathrm{kg}$ & 150 & 250 & 250 & 250 & 350 & 150 & 250 & 250 & 250 & 350 \\
\hline $\mathrm{ER}=(\mathrm{K}+\mathrm{Cl}) / \mathrm{Na}$ & & $3: 1$ & $2: 1$ & $3: 1$ & $4: 1$ & $3: 1$ & $3: 1$ & $2: 1$ & $3: 1$ & $4: 1$ & $3: 1$ \\
\hline
\end{tabular}

* EB - electrolyte balance; $E R$ - electrolyte ratio.

** Vitamin and mineral supplement - composition per kg product: Vitamin A, 1.335.000IU; vitamin D3, 300.000IU; vitamin E, 2.000mg; vitamin K3, 335mg; vitamin B1, 167mg; vitamin B2,670mg; vitamin B6, 170mg; vitamin B12, 1.670mcg; folic acid, 67mg; biotin, 7mg; niacin, 4.670mg; calcium pantothenate, $1.870 \mathrm{mg} ;$ copper, 1.000mg; cobalt, 17mg; iodine, 170mg; iron, $8.335 \mathrm{mg}$; manganese, $10.835 \mathrm{mg}$; zinc, $7.500 \mathrm{mg}$; selenium, 35mg; choline chloride 50\%, 83.340mg; methionine, 235.000mg; coccidiostat, 10.000mg; growth promoter, $10.000 \mathrm{mg}$; antioxidant, $2.000 \mathrm{mg}$. Inclusion of $6 \mathrm{~kg}$ of the supplement per tonne of feed.

*** Vitamin and mineral supplement - composition per kg product: Vitamin A, 1.670.000IU; vitamin D3, 335.000IU; vitamin E, 2.335mg; vitamin K3, 400mg; vitamin B1, 100mg; vitamin B2, 800mg; vitamin B6, 200mg; vitamin B12, 2.000mcg; folic acid, 67mg; biotin, 7mg; niacin, 5.670mg; calcium pantothenate, 2.000mg; copper, 2.000mg; cobalt, 27mg; iodine, 270mg; iron, 16.670mg; manganese, $17.335 \mathrm{mg}$; zinc, $12.000 \mathrm{mg}$; selenium, 70mg; choline chloride 50\%, 100.000mg; methionine, 235.000mg; antioxidant, 2.000mg. Inclusion of $3 \mathrm{~kg}$ of the supplement per tonne of feed. 
Birds were submitted, according to treatment (33 or 46 days of age), to acute heat stress (GonzalezEsquerra \& Leeson, 2005), mimicking commercial production conditions when there is power outage, and consequently cooling and evaporation systems stop working. Under these conditions, birds suffer from heat stress due to high environmental temperature and air relative humidity, in addition to high ammonia concentrations. Temperature was maintained between $35-38^{\circ} \mathrm{C}$ for $4 \mathrm{~h}$ on days 25 and 35 by covering the pens corresponding to the heat-stress treatment with a transparent plastic canvas and providing a heat source (porcelain cones with a 600w resistance) controlled by a thermostat. Birds were offered feed and cold water ad libitum during the entire experimental period, including the days when heat-stress was applied.

The following performance parameters were evaluated on days 33 and 46: body weight gain (g/bird/ period), feed intake ( $\mathrm{g} / \mathrm{bird} /$ period), feed conversion ratio, and mortality rate. Feed conversion ratio was calculating by dividing feed intake by weight gain. All dead birds were weighed and their body weight used to correct feed conversion ratio. During the heat-stress periods, mortality was recorded according to treatment, body weight, and age. Dead birds were disposed in a compost pile located in the experimental facilities.

The following micro-climatic conditions inside the broiler house and at the pens: air temperature (dry-bulb temperature), black globe temperature, air relative humidity, and air velocity. Average microclimatic parameters inside the house were obtained by an automated weather station placed at the center of the house. Air temperature and relative humidity were detected by a sensor placed inside a weatherresistant shelter with reading ranges of -40 to $60^{\circ} \mathrm{C}$ for temperature and 0 to $100 \%$ for relative humidity. Air velocity was determined with the aid of an ultrasonic anemometer, with 0-60 m.s. 1 resolution. All records were managed and stored using a multi-channel data acquisition system (CR10, Campbell Scientific). Temperature and relative humidity were monitored using the Ibutton $\AA$ in five pens (except for air velocity, which was measured in a single pen) among the birds in treatments not submitted to heat stress. In birds submitted to heat stress, those parameters were measured only on the heat stress days in five pens (one per electrolyte balance treatment).

Five birds per experimental unit (15 birds per treatment), with body weight close to the average of the respective replicate, were selected on day 46 for carcass yield evaluation. These birds were sacrificed, plucked, and eviscerated. The abdominal fat pad (adipose tissue around the bursa, proventriculus, gizzard, and cloaca) was removed and its weight calculated relative to broiler weight at sacrifice. The eviscerated carcass, with no head, feed, and neck, was weighed again to calculate carcass yield relative to live weight. The carcass was then cut up, and the yield of the bone-in parts (whole breast, legs (thighs and drumsticks), and wings) was calculated relative to carcass yield.

The obtained parts and the remaining carcass were ground, and sample was collected and freeze-dried for total lipid composition analysis. The lipid content of the carcass samples was determined by extraction in Soxhlet apparatus, using ethyl ether as solvent.

Data were submitted to analysis of variance to verify the effect of treatments, and then to analysis of regression to evaluate the effects of each supplementation level, according to the PROC GLM of SAS system (SAS Institute, 2000). Means were compared by the Student's t-test.

All parameters described in percentages were normalized for statistical analysis by transformation in arcsine $\sqrt{X / 100}$

\section{RESULTS AND DISCUSSION}

Maximum average environmental temperatures were 37.3 and $29.5^{\circ} \mathrm{C}$ on the first and second heatstress days, respectively. The remaining of the house was under thermoneutral conditions $\left(19^{\circ} \mathrm{C}-62 \%\right)$

Live weight, feed intake, and feed conversion ratio were influenced by heat stress. Birds submitted to heat stress both on day 25 and day 45 presented reduced live weight, increased feed intake, and worse feed conversion ratio (Table 5). These results are consistent with the observations of Plavnik \& Yahav (1998), who reported progressive reduction of body weight, weight gain, feed intake, and feed efficiency of broilers submitted to high environmental temperatures. This worse performance may be explained by the fact that, in an attempt to adapt to heat stress, birds reduce their feed intake to try to reduce endogenous heat production (Teeter et al., 1985). Bonnet et al.(1997) concluded that broilers submitted to heat stress gained $50 \%$ less weight than those maintained in thermoneutral conditions.

Most literature studies agree on the EB figure of $250 \mathrm{mEq} / \mathrm{kg}$ for broiler diets (Mongin, 1981; Johnson \& Karunajeewa, 1985; Vieites et al., 2004; Borges, 2006). However, only Mongin (1981) mentions electrolyte ratio requirements and recommends a value 
higher than 1 in broiler diets, but does not provide any precise figure. Therefore, further studies on this subject are needed (Borgatti et al., 2004).

In the present experiment, the diets with an EB of 250 $\mathrm{mEq} / \mathrm{kg}$ resulted in better feed conversion ratio (Table 5). However, the results show that diet formulation should also take into account ER, because the broilers fed the experimental diet with $250 \mathrm{mEq} / \mathrm{kg}$ and an ER value of 3 presented better feed conversion ratio relative to those fed the other diets, both on days 33 and 46.

Because linear feed formulation does not allow the use of ratios, because division is unfeasible in the software, it was not possible to apply of the full concept of Mongin (1981), that is, to supply in the diet, simultaneously: 1 - minimum $\mathrm{Na}^{+}, \mathrm{K}^{+}$e $\mathrm{Cl}^{-}$requirements, 2- EB of $250 \mathrm{mEq} / \mathrm{kg}$, and 3- ER $>1$. This has probably limited the research on dietary electrolyte balance for many years. However, the recent publication of the PPFR spreadsheet (Garcia Neto, 2011), which applies a non-linear concept, allows formulation changes such as those applied in the present experiment, and therefore, to check for nutritional imbalances, as reported by Ravindran et al. (2008). Unbalanced ratios among $\mathrm{K}^{+}, \mathrm{Cl}^{-}$, and particularly $\mathrm{Na}^{+}$, may limit the absorption of amino acids and other nutrients (Ravindran et al.,.2008). This problem may be circumvented by the application of the electrolyte combination (both EB and ER) concept, thereby preventing imbalances among electrolytes and their consequences on broiler growth.
The results of the present experiment show that broilers fed diets with adequate electrolyte balance were more tolerant to heat stress. The broilers submitted to acute heat stress at 25 and 35 days of age $\left( \pm 36^{\circ} \mathrm{C}\right.$ for $4 \mathrm{~h}$ ) and fed diets with an EB/ER of 350/3:1 dealt more efficiently with this extreme impact, as shown by their lower mortality rate (Table 6).

When broilers are submitted to acute heat stress, in addition to high temperature and high humidity, they are also exposed to high ammonia levels. The association of these three factors may have been the cause of the high mortality observed in this experiment, as it is difficult to separate their individual effects on bird survival. However, the mortality rate of the broilers fed a diet with the combination of an electrolyte balance of $350 \mathrm{mEq} / \mathrm{kg}$ and an electrolyte ratio of 3:1 was clearly lower, demonstrating that these birds were capable of maintaining their better acid-base homeostasis and suffered less changes caused by acute stress, including respiratory alkalosis.

The importance of supplying optimal $\mathrm{Na}+, \mathrm{K}+\mathrm{e}$ $\mathrm{Cl}$ - levels in broiler diets is that, during heat stress, the competition between $\mathrm{H}+\mathrm{e} \mathrm{K}+$ in the renal tubules is reduced. During alkalosis, extracellular $\mathrm{K}+$ enters the cell, consequently increasing the secretion of this ion in the renal tubule lumen. Under these conditions, $\mathrm{H}+$ is exchanged by $\mathrm{K}+$ in the renal tubule. The increasing $\mathrm{K}+$ secretion reduces its blood concentration, which causes circulation disorders in broilers, leading to death.

Table 5 - Effects of different combination of electrolyte balance $\left(\mathrm{Na}^{+}+\mathrm{K}^{+}-\mathrm{Cl}^{-}\right)$and electrolyte ratio $\left[\left(\mathrm{K}^{+}+\mathrm{Cl}^{-}\right) / \mathrm{Na}^{+}\right]$in the diet of broilers submitted to acute heat stress with 25 or 35 days old on their weight gain (WG), feed intake (FI), and feed conversion ratio (FCR) between 1 and 46 days of age.

\begin{tabular}{|c|c|c|c|c|c|c|}
\hline Factors** & $\mathrm{FI}$ & WG & FCR & $\mathrm{Fl}$ & WG & FCR \\
\hline Diet (EB/ER) & & 33 days & & & 46 days & \\
\hline $150 / 3$ & 3027.4 & 1937.4 & $1.62 b$ & $5230.7 b$ & 3491.7 & $1.76 \mathrm{ab}$ \\
\hline $250 / 2$ & 3062.6 & 2015.8 & $1.58 \mathrm{ab}$ & $5326.0 \mathrm{ab}$ & 3553.2 & $1.82 \mathrm{~b}$ \\
\hline $250 / 3$ & 3044.9 & 2024.4 & $1.55 a$ & $5447.4 a b$ & 3546.1 & $1.76 a$ \\
\hline $250 / 4$ & 3032.3 & 2001.7 & $1.57 a$ & $5351.7 a b$ & 3423.0 & 1.78ab \\
\hline $350 / 3$ & 3079.8 & 2012.1 & $1.58 a b$ & $5560.8 a$ & 3537.3 & $1.78 a b$ \\
\hline \multicolumn{7}{|l|}{ Heat stress } \\
\hline No & $2026.0 a$ & $3093.5 a$ & 1.57 & $3660.7 a$ & $5784.5 a$ & $1.78 a b$ \\
\hline 25 days & $1942.9 b$ & $2961.1 b$ & 1.60 & $3464.7 b$ & $5272.6 b$ & $1.76 b$ \\
\hline 35 days & ------ & ----- & ---- & $3394.9 b$ & $5092.8 b$ & $1.81 \mathrm{a}$ \\
\hline Feed $(F)$ & $\ldots$ & $\ldots$ & $\ldots$ & $\ldots$ & $\ldots$ & $\ldots$ \\
\hline Heat stress (S) & $\ldots$ & $\ldots$ & $\ldots$ & $\ldots$ & $\ldots$ & $\ldots$ \\
\hline$F * S$ & $\ldots$ & $\ldots$ & $\ldots$ & $\ldots$ & $\ldots$ & $\ldots$ \\
\hline CV $(\%)$ & $\ldots$ & $\ldots$ & $\ldots$ & $\ldots$ & $\ldots$ & $\ldots$ \\
\hline
\end{tabular}

${ }^{\star} \mathrm{EB}=$ electrolyte balance $(\mathrm{mEq} / \mathrm{kg}) ; \mathrm{ER}=$ electrolyte ratio.

** Non-significant interaction among factors (electrolyte combination $\mathrm{x}$ heat stress).

a-c Means followed by the same letter in the same column, within each factor, are not different by the Student's t-test at $5 \%$ probability level. 


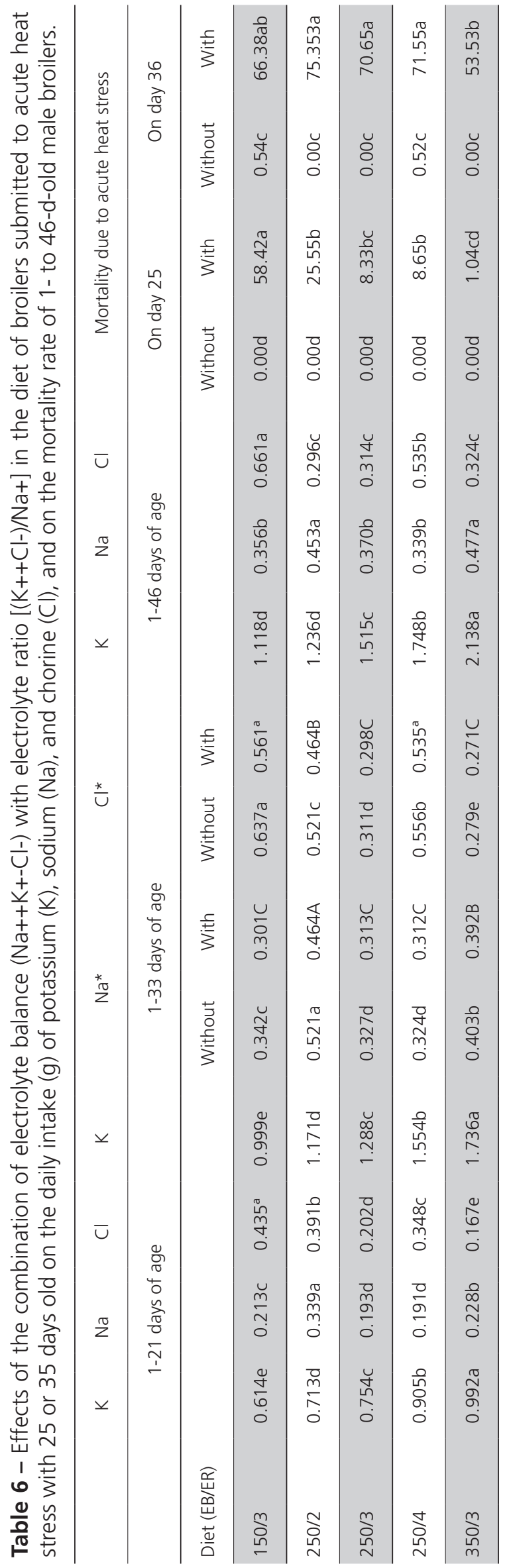

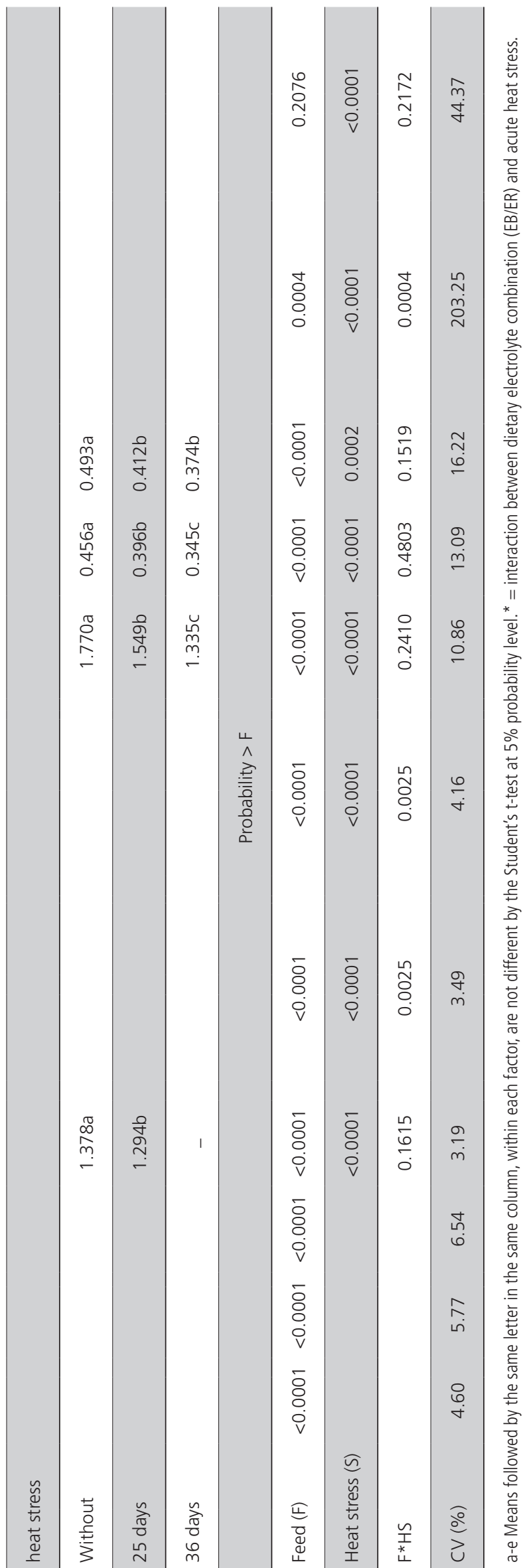


Therefore, during heat stress, that ion is essential for broiler survival (Macari et al., 2002), as shown by the lower mortality rate of broilers fed the diet with higher $\mathrm{K}+$ levels.

Broilers exposed to heat stress usually present higher carcass yield because of the slower viscera and feather development (Ain Baziz et al., 1996). However, this higher carcass yield does not compensate for the lower weight gain of broilers reared in hot environments. The results of the present experiment are consistent with literature reports of higher leg yield and lower breast yield of broilers exposed to heat stress (Temim et al.,
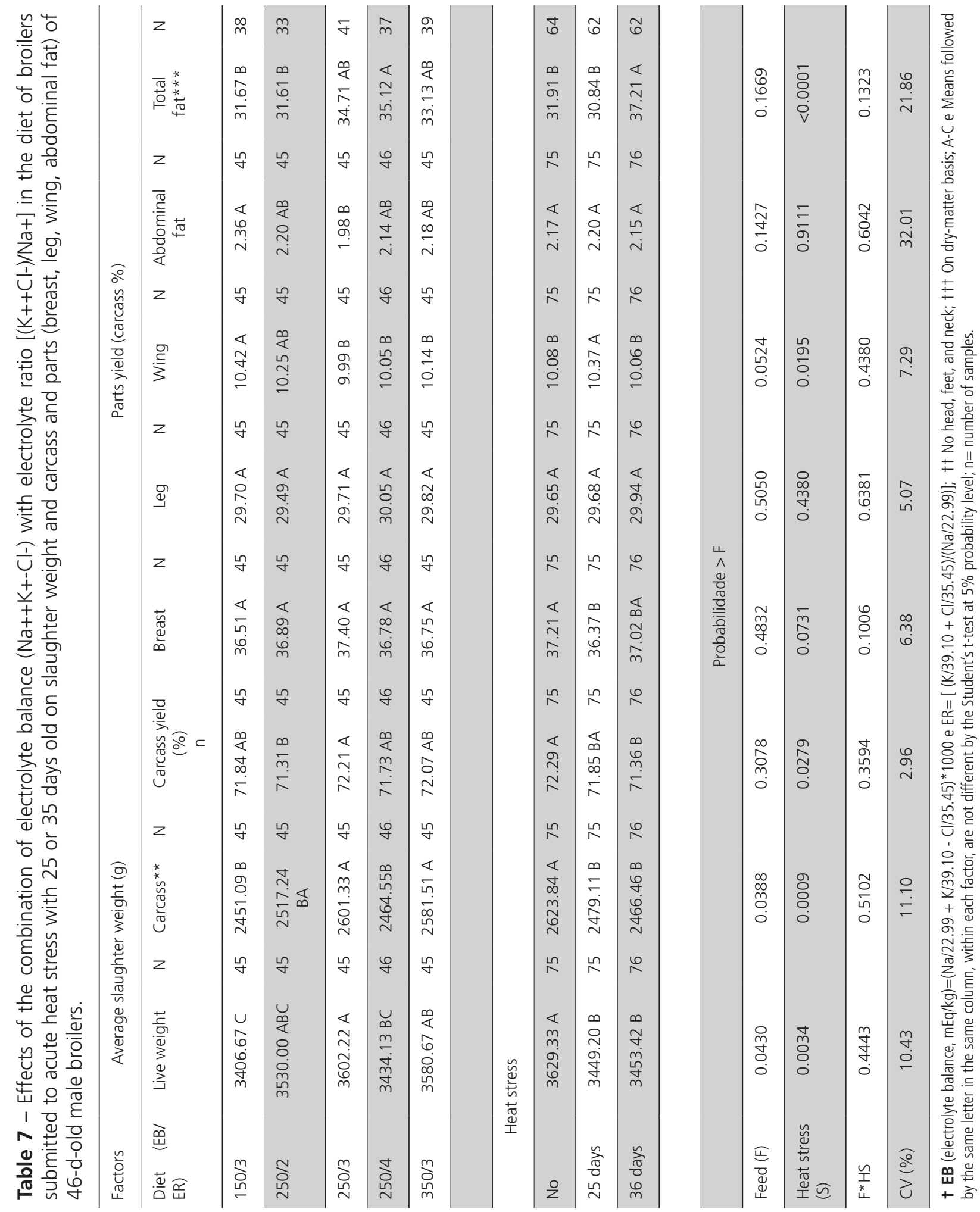
1999; Temim et al., 2000b; Faria Filho, 2003) These findings are associated with the different metabolism of each specific tissue: the breast present glycolytic metabolism, whereas the leg muscles present oxidative metabolism (Ain Baziz et al., 1996).

The broilers exposed to heat stress on day 36 presented higher carcass fat content between 22 and 46 days of age compared with the broilers submitted to heat stress on day 25 and with those not exposed to heat stress. The higher fat content and lower crude protein content of the broilers submitted to heat stress (Cheng et al., 1997a,b) results from their lower basal metabolism and physical activity (Ain Baziz et al., 1996).

The findings of the present experiment indicate that ER may potentially improve broiler performance and carcass quality, provided EB is concurrently adjusted, particularly under heat stress conditions (Table 7). The birds fed the diet with an EB of $250 \mathrm{mEq} / \mathrm{kg}$ and an ER of 3 were heavier at slaughter and presented heavier carcasses and lower abdominal fat content compared with those submitted to the other treatments. This is an important factor to be considered because consumers value heavy and lean chicken carcasses.

Considering that broilers exposed to high temperatures tend to habituate to these conditions, and that those temperatures negatively affect their productivity (Yahav \& McMurtry, 2001), it is essential to supply them a nutritionally adequate diet that provides support to prevent disorders caused by heat stress. For instance, there may be reduced weight gain, which may be subsequently compensated (Yahav \& McMurtry, 2001), and directed for body fat deposition and visceral growth or for protein accretion (Zhan et al., 2007; Rutz, 2011).

\section{CONCLUSIONS}

The strategic formulation considering the precise electrolyte balance, including $E B$ and $E R$, improves broiler performance and may prevent the negative effects of heat stress.

Under thermoneutral conditions, an EB of $250 \mathrm{mEq} /$ $\mathrm{kg}$ and an ER of 3 are recommended, whereas under heat stress, an EB of $350 \mathrm{mEq} / \mathrm{kg}$ and an ER of 3 to obtain better performance and livability.

\section{ACKNOWLEDGEMENTS}

The authors thank Fundação de Amparo à Pesquisa do Estado de São Paulo (Fapesp) for funding (Fapespprocess n. 2008/08575-4).

\section{REFERENCES}

AinBaziz H, Geraert PA, Padilha JCF, Guillaumen S. Chronic heat exposure enhances fat deposition and modifies muscle and fat partition in broiler carcasses. Poultry Science 1996;75:505-513

Bonnet S, Geraert PA, Lessire M, Carre B, Guillaumen S. Effect of high ambient temperature on fees digestibility in broilers. Poultry Science 1997;76(6):857-863.

Borgatti LMO, Albuquerque R, Meister NC, Souza LMO, Lima FR, Trindade Neto MA. Performance of broilers fed diets with different dietary electrolyte balance under summer conditions. Brazilian Journal of Poultry Science 2004;6:153-157.

Borges SA. Aplicação do conceito de balanço eletrolítico para aves. Anais da Conferência APINCO 2006 de Ciência e Tecnologia Avícolas, 2006; Santos, São Paulo. Brasil. p.123-137

Cahaner A, Leenstra F. Effects of high temperature on growth and efficiency of male and female broilers from lines selected for high weight gain, favorable feed conversion, and high or low fat content. Poultry Science $1992: 71: 1237-1250$

Cheng TK, Hamre ML, Coon CN. Effect of environmental temperature, dietary protein, and energy levels on broiler performance. Journal of Applied Poultry Research 1997a;6:1-17

Cheng TK, Hamre ML, Coon CN. Responses of broilers to dietary protein levels and amino acid supplementation to low protein diets at various environmental temperatures. Journal of Applied Poultry Research 1997b;6:18-33

Faria Filho DE. Efeito de dietas com baixo teor protéico, formuladas usando o conceito de proteína ideal, para frangos de corte criados em temperaturas fria, termoneutra e quente [dissertação]. Jaboticabal (SP): Universidade Estadual Paulista; 2003. 93 f

Garcia Neto M. Programa prático para formulação de rações / frangos de corte PPFR / tabelas brasileiras 2005 [cited 2012 Abr 10]. Available from: http://www.fmva.unesp.br/ppfr.

Gezen SS, Eren M, Deniz G. The effect of different dietary electrolyte balances on eggshell quality in laying hens. Revue de Médecine Véterinaire 2005;156:491-497

Gonzalez-Esquerra R, Lesson S. Effects of acute versus chronic heat stress on broiler response to dietary protein. Poultry Science 2005;84:15621569 .

Johnson RJ, Karunajeewa $\mathrm{H}$. The effects of dietary minerals and electrolytes on the growth and physiology of the young chick. Journal of Nutrition 1985;115:1680-1690.

Judice JPM, Bertechini AG, Muniz JÁ, Rodrigues PB, Fassani JE. Balanço cátio-aniônico das rações e manejo alimentar para poedeiras de segundo ciclo. Ciência Agrotécnica 2002;26:598-609.

Macari M, Furlan RL, Gonzales E. Fisiologia aviária aplicada a frangos de corte. $2^{a}$ ed. Jaboticabal: FUNEP/UNESP; 2002. 375p.

Mongin P. Recent advances in dietary anion-cation balance: application in poultry. Proceedings Nutrition Society 1981;40:285-294

NRC - National Reseach Council. Nutrient requirements of poultry. $9^{\text {th }}$ ed Washington (DC): National Academy Press; 1994. 155p.

Plavnik I, Yahav S. Effect of environmental temperature on broiler chickens subjected to growth restriction at an early age. Poultry Science $1998 ; 77: 870-872$

Ravindran V, Cowieson AJ, Selle PH. Influence of dietary electrolyte balance and microbial phytase on growth performance, nutrient utilization, and excreta quality of broiler chickens. Poultry Science 2008;87:677-688. 


\section{Minimize Heat Stress in Broilers}

Rostagno HS, Albino LFT, Donzele JL, Gomes PC, Oliveira RF, Ferreira AS, et al. Tabelas brasileiras para aves e suínos: composição de alimentos e exigências nutricionais. 2.ed. Viçosa: Universidade Federal de Viçosa; 2005. 186p.

Rutz F, Gentilini FP, Gonçalves FM, Roll AP, Santos VL. Considerações sobre alimentação programada [cd-rom]. Anais da $48^{\text {a }}$ Reunião Anual da Sociedade Brasileira de Zootecnia; 2011; Belém, Pará. Brasil. p. 1-6.

SAS Institute. Users guide: statistics. $5^{\text {th }}$ ed. Cary; 2000.

Talbot CJ. Sodium, potassium and chloride imbalance in broiler diets.

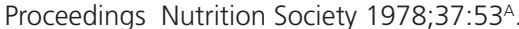

Teeter RG, Belay T. Broiler management during acute heat stress. Animal Feed Science and Techonology 1996;58:127-142.

Teeter RG, Smith MO, Owens FN, Arp SC, Sangiah S, Breazile JE. Chronic heat stress and respiratory alkalosis: occurrence and treatment in broiler chicks. Poultry Science 1985;64:1060-1064.

Temim S, Chagneau AM, Guillaumin S, Michael J, Peresson R, Gerovert PA, et al. Effects of chronic heat exposure and protein intake on growth performance, nitrogen retention and muscle development in broiler chickens. Reproduction, Nutrition, Development 1999:39:145-156.
Temim S, Chagneau AM, Peresson R, Tesseraud S. Chronic heat exposure alters protein turnover of three different skeletal muscles in finishing broiler chickens fed 20 or $25 \%$ protein diets. Journal of Nutrition 2000b; 130:813-819.

Tinoco IFF. Resfriamento adiabático evaporativo na produção de frangos corte [dissertação]. Viçosa (MG): Universidade Federal de Viçosa; 1988.

Vieites FM, Moraes GHK, Albino LFT, Rostagno HS, Atencio H, Vargas Junior JG, et. al. Balanço eletrolítico e níveis de proteína bruta sobre o desempenho de pinto de corte de 1 a 21 dias de idade. Revista Brasileira de Zootecnia 2004;33(6):2076-2085.

YahavS, Mcmurtry JP. Thermotolerance acquisition in broiler chickens by temperature conditioning early in life - the effect of timing and ambient temperature. Poultry Science 2001; 80:1662-1666.

Yalcin S, Ozkan S, Turkmut L, Siegel PB. Responses to heat stress in commercial and local broiler stacks. 1. Performance traits. British Science 2001:42:149-152.

Zhan XAn Wang Mn Ren H, Zhao RQ, Li JX, Tan ZL. Effect of early feed restriction on metabolic programming and compensatory growth in broiler chickens. Poultry Science 2007; 86:654-660. 
